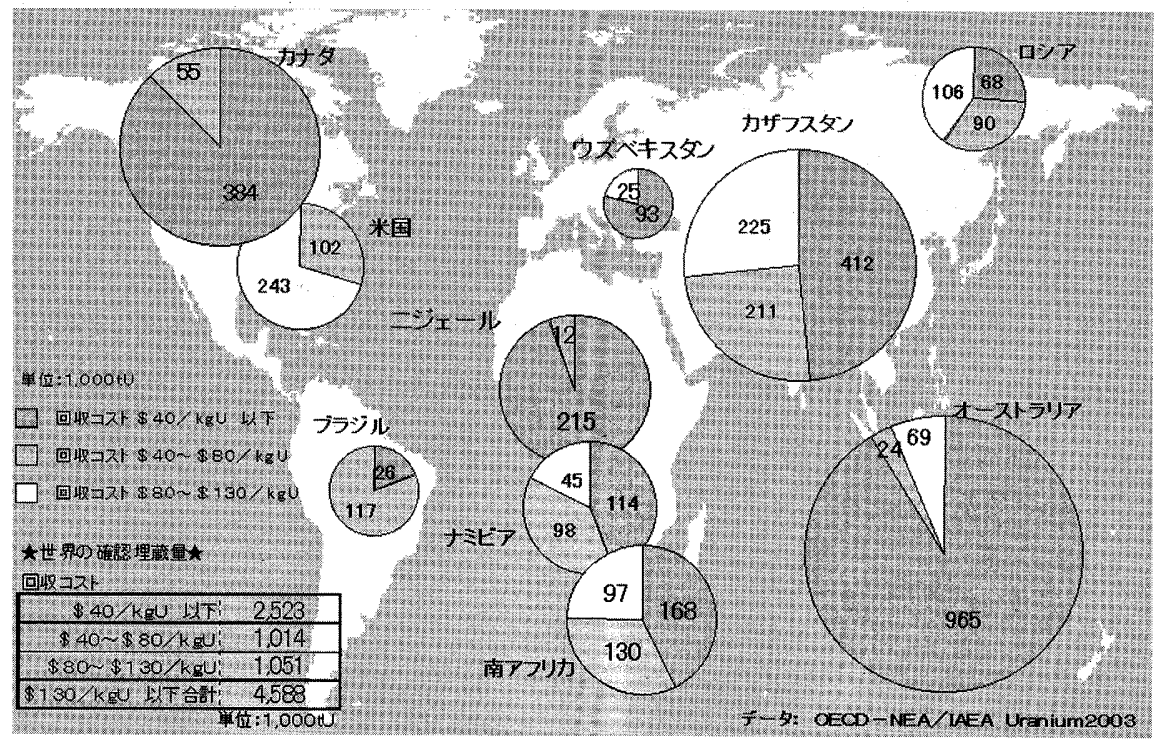

図 1 世界のウラン資源埋蔵量

続け，探鉱活動も規模が大幅に縮小された。また，中小の生 産者が撤退した結果, ウラン市場の寡占化が進んだ（2002年 には，上位 4 生産者で年間ウラン生産量の $60 \%$ を生産 ${ }^{1)}$ 。

\section{(2) ウランの需給の今後の見通し}

ところが，西側の余剩在庫も2010年代前半には払底すると 思われること, ロシア解体核ウランの供給も国内の需要増な どで先行きが不透明であることから，WNAでは，2013年以降 にウランの供給が不足する可能性があると予測している。

こうした予測に歩調を合わせるように，過去10年あまり比 較的低位安定していたウランの市場価格は，2003年後半より 急激な上昇を続けている。民間の調查会社が発表するウラン のスポット価格は，2003 年半ばまで $\$ 10 / \mathrm{lbU} 308(26 \$ / \mathrm{kgU})$ 前後で推移していたが，その後上昇に転じ，今年 5 月に入っ て\$26/lbU308（68\$/kgU）を超えた。

このウラン価格高騰の背景には，2003年に発生したウラン 鉱山での複数のトラブルもあるが，これらはあくまで一時的 な要因であり，長期にわたる価格上昇の背景には，今後のウ ラン供給不足への危機意識があると考えられている。

また，原子力発電所の新増設を計画している中国の動向も， こうした危機意識に拍車をかける結果となっている。

\section{2. ウラン資源の分布と探鉱活動}

ウラン資源は世界に広く分布しており, OECD/IAEAの発表 によれば，2003年時点の埋蔵量（既知資源）は約 460 万tUで あり, オーストラリア, カナダ, カザフスタン, アフリカ諸 国に多くの埋蔵が確認されている2)(図 1 参照)。

昨今のウラン市場価格の高騰に伴い，探鉱活動が徐々に活 発化する動きが見られてはいるが，本格的な探鉱活動の再開 のためには，今後もウランの市場価格が一定レベルで推移す るであろうことをウラン生産者が確信することが必要である。 いずれにせよ，過去10年以上にわたり探鉱活動が殆ど行われ
てこなかった笑を埋めることは困難であり，至近のウラン供 給不足への懸念が払拭されたわけではない。

\section{文 献: References}

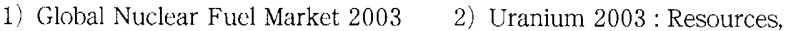
Production \& Demand

\section{2 原子力発電の現状}

\section{1. 原子力発電所の運転・建設状況}

平成16年度末現在におけるわが国の営業運転中の原子力発 電所は，中部電力浜岡 5 号機が本年 1 月に営業運転開始した

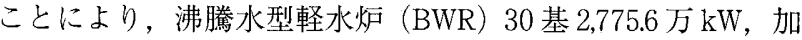

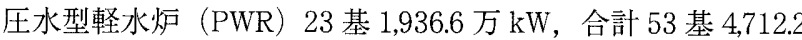
万 $\mathrm{kW}$ あ゙あ，これらによる 16 年度総発電電力量は，約 2,779 億 $\mathrm{kWh}$ となっている。

また，平成16年度末現在，建設中の原子力発電プラントは 3 基 337.0 万 $\mathrm{kW}$ ，着工準備中は 12 基 1631.8 万 $\mathrm{kW}$ となって いる(表 1 参照)。

平成16年度における原子力発電プラントの設備利用率は全 プラント平均で $68.9 \%$ であった。平均設備利用率は, 昭和 58 年度に $70 \%$ を超えて以来， 20 年連続で $70 \%$ 以上を維持してい たが，平成14年夏以降の東京電力の一連の原子力の不祥事等 に起因する点検の必要性等から，定期検查期間が長期化した こともあり，平成 15 年度実績 $(59.7 \%)$ は上回ったものの引 続き $70 \%$ を下回る結果となった。

設備利用率のロスとしては，およそ 1 年に 1 回実施してい る定期検査による停止に伴うものが $28.3 \%$ を占めている。一 方，トラブルによるロスは $0.7 \%$ となっている。な打平成 16 年 度の法律に基づき報告されたトラブルの件数は 20 件であり， 
表 1 原子力発電所の運転・建設状況

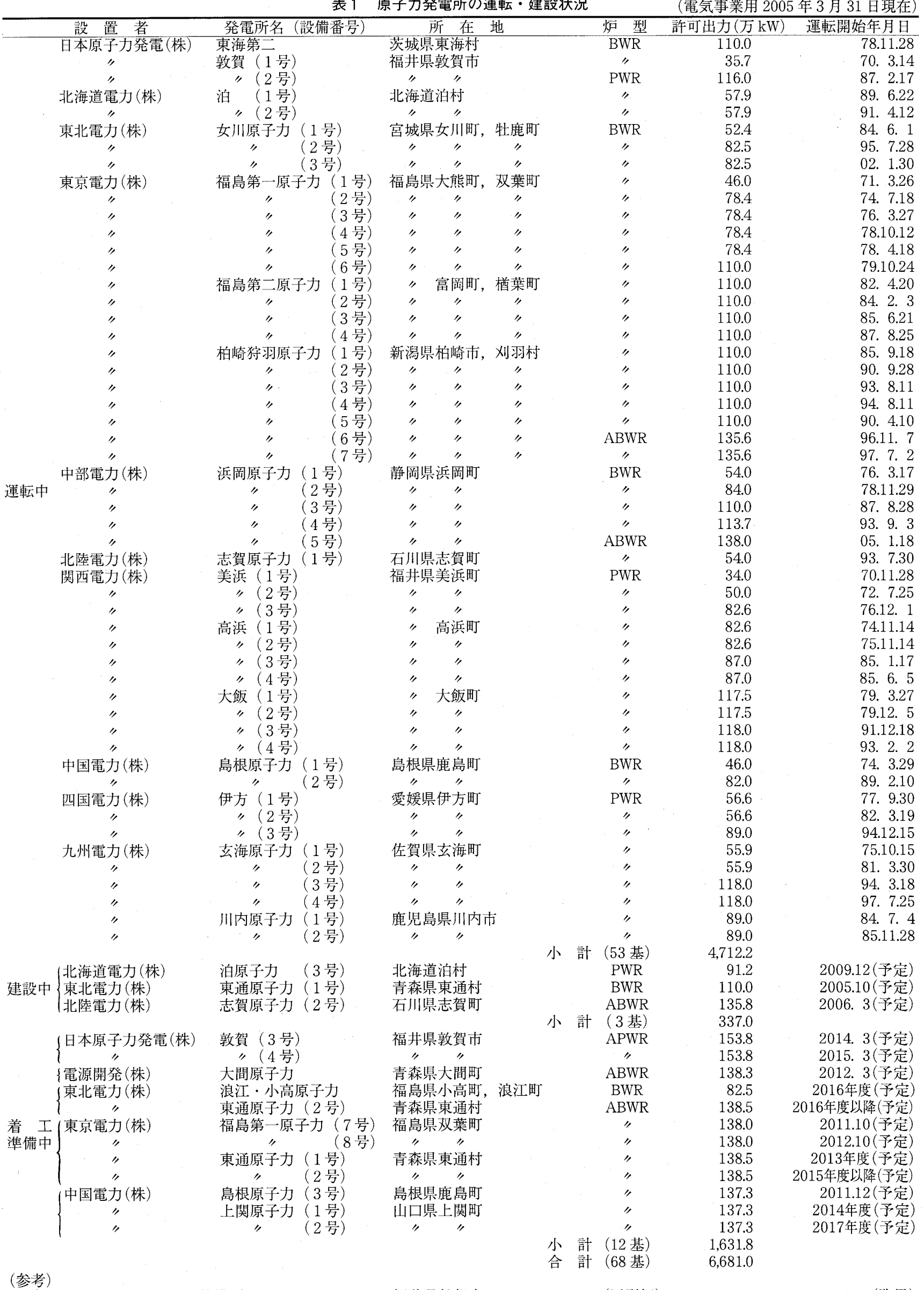


原子炉 1 基当たりの件数としては約 0.4 件であった。これらの トラブルの国際原子力事象評価尺度（INES）による評価は, 「安全上重要でなく, 安全に影響を与えない事象（レベル 0 一)」が18件，「安全上重要でないが，安全に影響を与え得る

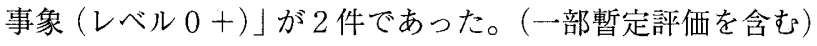

\section{2. 今後の原子力開発}

平成16年度末に各電力会社が公表した原子力発電所の開発 計画によれば, 2014 年度 (平成 26 年度) までに運転開始が予 定されている原子力発電所は, 11 基 $1,472.0$ 万 $\mathrm{kW}$ (うち, 現 在建設中のプラントが 3 基 337.0 万 $\mathrm{kW}$ ，今年度着工予定が 1 基 137.3 万W）となっている。また全体の原子力開発計画と しては，2015年度 (平成 27 年度) 以降に運転開始を予定して いる 4 基を加えて，15 基 $1,968.8$ 万 $\mathrm{kW}$ となっている。

なお， 2010 年度 (平成 22 年度) までに運転開始する原子力 発電所は，昨年度計画では 5 基となっていたが，昨年度中に 運転開始したプラントや，運転開始を繰り延ベたプラントが あったため，今回の計画では 3 基 337.0 万 $\mathrm{kW}$ となっている。

\section{3 原子燃料サイクル}

\section{1. 原子燃料サイクル計画の具体化}

(1)ウラン濃縮

ウラン濃縮の遠心分離法の技術については，日本において も日本原燃(株)六ヶ所濃縮工場で実用化されている。同工場 は, 平成 4 年 3 月に年間 150 トンSWUの規模で操業を開始し, 順次拡大してきており，現在は年間 1,050トンSWUの施設规 模となっている。最終的には，年間 1,500トン SWU規模まで 拡大する予定である。

\section{(2) 再処理}

使用済燃料からまだ利用できるウランやプルトニウムを分 離して取り出す再処理については，これまでは主としてイギ リスとフランスに委託してきたが, 平成 5 年 4 月より, 商業 用再処理施設の建設が青森県六ケ所村で日本原燃(株)によっ て進められている。同施設の年間処理能力は 800 トンで，操 業開始は平成 19 年を予定しており, 平成 17 年 3 月末現在の 建設工事の進渉率は 96\%（設備関係についてはほぼ完成）で ある。また，これまでに通水作動試験，化学試験を実施して おり，昨年 12 月よりウラン試験を開始している。

なお，現時点で，国内唯一の再処理施設である核燃料サイ クル開発機構の東海再処理工場では, 累積再処理量が 1,000 卜 ンを超えている。

\section{(3) MOX 燃料利用}

\section{(1)プルサーマル計画}

わが国では，再処理によって得られるプルトニウムを原子 燃料として再利用していくことを基本としており，政府は平
成 9 年 2 月にプルサーマル（MOX 燃料（ウラン・プルトニウ 么混合酸化物然料）を軽水炉等のサーマル・リアクター（熱 中性子炉）で使うこと）を早急に開始することが必要である との閣議決定を行った。それを受けて，各電気事業者は2010 年までに全国 16 ～ 18 基の原子炉でプルサーマルを行うこと を目標として準備を進めている。

このうち，最初に導入するべく準備を進めていた東京電力 の福島第一 3 号機と柏崎刈羽 3 号機, 関西電力の高浜 3 号機, 4 号機については，地元の事前了解などを取得したものの，そ の後のJCO事故の発生や関西電力用のMOX燃料を製造したイ ギリス・BNFL社における製造時の品質管理データねつ造の発 覚，福島県におけるエネルギー政策全般に関する検討会の開 催，新潟紧刈羽村におけるプルサーマル導入に関する住民投 票と反対多数の結果等の経緯があり，実施を見送ってきた。さ らに，東京電力では平成 14 年 8 月の原子力発電所の点検・補 修作業に係る不適切な取扱いの公表等により，福島・新潟両 県から事前了解を取り消され，実施の目途がたたない状況と なっている。

また, 関西電力では, 平成 14 年 9 月に不正デー夕問題が あった MOX 燃料の BNFL 社への返送が完了し，平成 16 年 3 月，高浜発電所での計画を進めていくことの地元了解を得て， 海外加工メーカ一等とMOX燃料の調達に関する基本契約を締 結したが，昨年 8 月の同社美浜 3 号機の配管破損事故により， 計画的な推進が危惧されている。現在, 同社では事故の再発 防止対策に取り組むとともに，地元等の理解を得ながら計画 の㬰現に间けて努力していくこととしている。

一方，上記 2 社以外の動向としては，九州電力および四国 電力で計画推進に向けての具体的な動きが見られている。九 州電力では, 昨年 4 月に玄海 3 号機での計画を表明し 5 月に は国へ原子炉設置変更許可を申請した。四国電力では, 昨年 5 月に伊方 3 号機での計画の表明をして11月に国へ原子炉設 置変更許可を申請した。現在, 両社ともに地元からの計画実 施の了解を得ることに向けて，理解活動を継続的に実施して いるところである。

\section{(2) MOX 燃料加工工場}

現在，プルサーマル用のMOX燃料は，ヨーロッパの燃料加 工工場へ製造を委託しているが，将来のプルサーマル本格時 代に備えて, 国内でのMOX然料加工工場の建設を計画してい る。

平成 12 年 11 月に, 日本原然(株)は, 電気事業連合会の要 請によりMOX 燃料加工に関する事業主体となることを表明。 平成13年 8 月に，青森県ならびに六ヶ所村に対して工場の立 地協力要請を行い，本年 4 月には「MOX 燃料加工施設の立地 への協力に関する基本協定」を締結した。日本原燃(株)では 同月，国に核然料物質加工事業許可申請を行い，最大加工能 力が年間 130 トンで，平成 24 年の竣工を計画している。

\section{(4) 使用済燃料の中間貯蔵}

現在六ヶ所村で建設中の再処理工場の処理能力は, 国内の 